\title{
Invasive ants reduce carbon fixation for a foundational East African ant-plant
}

\author{
Patrick Milligan ${ }^{1}$, Timothy Martin ${ }^{1}$, Grace John ${ }^{1}$, Corinna Riginos ${ }^{2}$, Jacob Goheen ${ }^{3}$, Scott \\ Carpenter ${ }^{4}$, and Todd Palmer ${ }^{1}$ \\ ${ }^{1}$ University of Florida \\ ${ }^{2}$ The Nature Conservancy \\ ${ }^{3}$ Univ Wyoming \\ ${ }^{4}$ Yale University
}

September 11, 2020

\begin{abstract}
Invasive ants shape assemblages and interactions of native species, but their effect on fundamental ecological processes is poorly understood. In East Africa, the big-headed ant (Pheidole megacephala) invades monodominant stands of the anttree Acacia drepanolobium, displacing native ant defenders and rendering trees vulnerable to elephants (Loxodonta africana) and other browsing ungulates. We quantified A drepanolobium photosynthesis and transpiration pre- and post-invasion by P. megacephala. After ca. 5 years, ant invasion resulted in $69 \%$ lower whole-tree carbon fixation during the growing season, despite shorter-term ( $<1$ year) positive effects on photosynthetic rates coinciding with the displacement of energetically costly native ants. By experimentally excluding ants and large herbivores, we demonstrate that reduced carbon fixation resulted largely from browsing on trees by large herbivores in invaded areas. Our results from individual trees likely scale up, highlighting the potential of invasive species to alter carbon fixation and other biogeochemical cycles at ecosystem scales.
\end{abstract}

\section{Introduction}

Non-native insects can profoundly affect ecological communities, threatening biodiversity (Pimentel et al. 2001; Englund 2008; Hill et al. 2013), disrupting important ecological processes (forest canopy structure, biogeochemical cycles, Gandhi \& Herms 2010; suppressing native foundational species, McGeoch et al. 2015), and imposing large economic costs (Bradshaw et al. 2016; Painiet al. 2016). Invasive ants comprise $>240$ species, and often lead to shifts in the behavior, functional role, and abundance of their native counterparts (Holway et al. 2002; Bertelsmeieret al. 2017). In so doing, non-native ants can restructure pollination networks (Vanbergen et al. 2018), interrupt seed dispersal (e.g., Horvitz \& Schemske 1986; RodriguezCabal et al.2012) and pollination (e.g., Fuster et al. 2020), and spread diseases in pollinator communities (Vanbergen et al. 2018).

Although their community-level impacts are well documented and diverse, the consequences of ant invasions for biogeochemical cycles are poorly understood. In particular, effects of invasive ants might be expected to reverberate throughout ecosystems via shifts in carbon dynamics for several reasons. First, native ants, which are often displaced by invasive ants (Ness \& Bronstein 2004; Milligan et al. 2016), can directly modulate the spatial distribution of carbon (e.g., wood ants in subalpine forests, Risch et al. 2005; Finér et al. 2013), or engage in ant-plant mutualisms that influence host plant carbon dynamics (Pringle 2016). Second, invasive ants can feed on extrafloral nectar of host plants (Ness \& Bronstein 2004; Lach et al. 2009) and collect honeydew from heterospecific insect partners (Beardsleyet al. 1982; Zhou et al. 2017; Demian \& Tarnita 2019; Anastasio 2020). Ant interactions with nectaries or with phloem-feeding insects can affect 
the carbon source-sink ratio of host plants (Albaniet al. 2010; Del-Claro et al. 2016; Prior \& Palmer 2018) which can increase or decrease leaf carbon exchange rates (Goldschmidt \& Huber 1992; Nebauer et al. 2011). Third, invasive ants can deter or facilitate herbivory on host plants with consequences for plant growth and overall canopy size (e.g., Savage et al. 2009; Lach \& Hoffmann 2011; Kulikowski II 2020), which may combine with changes to leaf carbon exchange rates to affect whole-plant carbon fixation. Finally, invasive ants could especially influence ecosystem carbon cycling by invading ant-plants that are dominant primary producers in some communities (e.g., devil's gardens, Frederickson et al.2005; Acacia drepanolobium savannas, Goheen \& Palmer 2010), such that invasion would have disproportionate effects on local carbon cycles.

We investigated how invasion by Pheidole megacephala Fabricius (the "big-headed ant") affects carbon cycling in a widespread and mono-dominant foundation species, the whistling thorn tree (Acacia drepanolobium ). Pheidole megacephala has invaded tropical and subtropical ecosystems around the world (Wetterer 2012), extirpating native ant mutualists (Ness \& Bronstein 2004; Riginos et al.2015), forming facultative partnerships with phloem-feeding insects (e.g., Beardsley et al. 1982; Gaigher et al. 2013), but otherwise suppressing abundance, distribution, and diversity of native insects (Ness \& Bronstein 2004; Hoffmann \& Parr 2008; Riginos et al. 2015; Milligan et al. 2016). In savannas underlain by clay-rich vertisols (i.e., 'black-cotton') savannas of Laikipia, A. drepanolobium comprises $>95 \%$ of woody cover (Young et al. 1996) and forms obligate mutualisms with four native ant species (Crematogaster mimosae Santchi, Crematogaster nigriceps Emery, Crematogaster sjostedtiMayr, and Tetraponera penzigi Mayr). Host plants exclusively house one native ant species at a time, producing extrafloral nectar and hollow spine domatia (e.g., Huntzinger et al. 2004) to feed and house thousands of ants (Palmer 2004). The most common mutualist, C. mimosae, consumes nectar and honeydew (Prior \& Palmer 2018) and reduces herbivory by large mammals (Stanton \& Palmer 2011) including elephants (Goheen \& Palmer 2010). In invaded habitats, C. mimosae mutualists are completely extirpated by $P$. megacephala, which does not deter herbivores (Riginos et al. 2015). However, and because $P$. megacephala does not consume extra-floral nectar, host trees may experience energetic savings immediately after invasion, even as longer-term costs (through risk of intense herbivory) increase. King and Caylor (2010) demonstrated that the prevention of herbivory by native ants influences photosynthetic rate of the host tree, but direct ant-plant interactions and the role of this invasive ant were not investigated in their study. Thus, both ant-plant and vertebrate-plant interactions are potential modes by which invasive ants may impact leaf photosynthetic rate (via source-sink dynamics) and canopy carbon fixation (via canopy damage by herbivores).

We conducted field experiments and observations to investigate how $P$. megacephala invasion affects carbon fixation in A. drepanolobium. Because the effects of invasion frequently lag behind the initial arrival of the invader (Simberloff 2011), we evaluated how P. megacephala invasion influences host plant carbon fixation over both the short- ( $<1$ year) and long-term ( $c a .5$ years). We investigated these short- and long-term impacts of invasion in wet and dry seasons during which host plant rates of photosynthesis can substantially differ (King \& Caylor 2010). We addressed three research questions regarding A. drepanolobium : (1) Does the leaf photosynthetic rate of $A$. drepanolobium change shortly after the extirpation of costly ant mutualists by P. megacephala? (2) Does the leaf photosynthetic rate of $A$. drepanolobium further change in long term invasion sites, and how is that rate influenced by ant-plant and vertebrate plant interactions? (3) How do vertebrate herbivores and invasive ants contribute to changes in canopy photosynthesis for invaded trees?

\section{Methods}

Study Site - Fieldwork was conducted from July 2017 to September 2018 at Ol Pejeta Conservancy ("OPC"; $0^{\circ} 0^{\prime} 52.62^{\prime \prime} \mathrm{N}, 36^{\circ} 51^{\prime} 58.64^{\prime \prime} \mathrm{E}, 1800 \mathrm{~m}$ above sea level). This $360 \mathrm{~km}^{2}$ conservancy receives $\mathrm{ca} .250-300 \mathrm{~mm}$ of rainfall in wet seasons (March to May; October to December, and intervening periods are typically dry and hot with monthly rainfall of $c a .30-50 \mathrm{~mm}$ (OPC records). The OPC elephant population ( $c a$. 130-300 depending on forage availability, OPC records) disproportionately imposes heavy damage on A. drepanolobium in areas where P. megacephala has invaded (Riginos et al. 2015). Ground-dwelling P. megacephala ants have expanded from human habitation areas on OPC into black-cotton savannas for the past $c a$. two decades (Riginos et al.2015), where they occupy trees and soil. During this study, P. megacephala extended each monitored 
invasion front by $c a .50 \mathrm{~m} / \mathrm{yr}$ (Pietrek et al. in revision).

Survey Regime - We measured leaf gas exchange (photosynthesis and transpiration) in concurrent BeforeAfter-Control-Impact (BACI) and factorial experiments (Fig. S3) during rainy and dry seasons. For each surveyed tree, we measured leaf water potential at mid-day and before dawn to 1) confirm assumptions that all sites had similar soil water status within each $c a$. 2-week survey period, 2) to confirm that our designations of "wet" and "dry" seasons were appropriate relative to studies of other East African acacias (Gebrehiwot et al. 2005; Gebrekirstos et al. 2006), and 3) to calculate leaf water potential range, which can be compared with leaf gas exchange rates to indicate changes in water management by the plant.

BACI experiment - To assess short-term impacts of $P$. megacephala invasion, we measured gas exchange rates and leaf water potential on the same trees before and after invasion, and compared those to concurrent measurements on uninvaded trees that were protected by native $C$. mimosae. We collected data from trees in plots near the invasion front ("Transition" sites) before and after invasion, and also surveyed non-manipulated trees $<1 \mathrm{~km}$ from each Transition site ("Control" sites) that remained unaffected by P. megacephala range expansion over the course of the study. All sites were accessible to large herbivores. In the July 2017 dry season and November 2017 wet season, we surveyed 20-24 adult trees (1.5-2 meters tall) at each Transition (pre-invasion) and Control sites. Pheidole megacephala workers expanded into Transition sites in December 2017, and we repeated surveys at each site in the May 2018 wet season and September 2018 dry season. Five trees were destroyed (evidently by elephants) between December 2017 and May 2018 and excluded from analyses.

Factorial experiment comparing long-term ( $>5$ years) impact of invasion - In the factorial experiment, we tested direct and indirect effects of invasive $P$. megacephala, native $C$. mimosae, and vertebrate herbivores on leaf and canopy gas exchange. We measured leaf water potential and gas exchange rates in two dry (July 2017 and September 2018) and two wet seasons (November 2017 and May 2018). Treatment factors were large herbivores (present vs. absent) and ants (present vs. absent), resulting in four treatments (Fig. S3). We conducted our experiment in three sites where acacias had been invaded for $c a .5$ years ("Invasion"), and in 3 neighboring ( $<2 \mathrm{~km}$ away) uninvaded sites with comparable tree density ("Uninvaded" sites). We constructed an electric fence exclosure at each site to exclude large herbivores $(>20 \mathrm{~kg})$ from a $50 \times 50 \mathrm{~m}$ plot (0.25-ha) containing $c a .40$ adult trees (1.5-2 meters tall). We marked 40 adult trees (1.5-2 $\mathrm{m}$ tall) in a plot of similar area and tree density $c a .200 \mathrm{~m}$ from each fenced plot to serve as unfenced controls. Each site comprised two plots, with a total of $c a$. 80 marked trees at each site. We fogged canopies with $0.6 \%$ alpha-cypermethrin (2-3 day half-life in full sunlight; World Health Organization public health specifications for insecticides) and applied sticky barriers (Tanglefoot @ Insect Barrier, Contech Enterprises, Victoria, BC, Canada) to the trunks of 20 trees (e.g., see Stanton and Palmer 2011) in each plot to remove and exclude ants, and reapplied both as needed.

Tree physiological measurements - We conducted all plant physiology measurements on fully-expanded leaves growing from non-lignified shoots in the unshaded sections of the upper canopy. Leaf-level light-saturated photosynthetic and transpiration rates [henceforth "leaf photosynthetic rate" ( $\left.A_{\text {max-leaf }}\right)$ and "leaf transpiration rate" $\left.\left(E_{\text {leaf }}\right)\right]$ were measured using a LI-6400XT Portable Photosynthesis System (Li-Cor Biosciences, Lincoln, NB) during sunny or partly cloudy days from 07:30-11:30. In long-term Invaded and Uninvaded sites, we also visually estimated canopy leaf area for a random subset of 7-17 acacias per treatment in our factorial experiment in 2018 ( $N=102$ in wet season, $N=61$ in dry season; means \pm SEM in Table S1), and multiplied estimated leaf area by leaf photosynthetic and transpiration rates to estimate idealized light-saturated whole-canopy photosynthesis and transpiration [henceforth "canopy photosynthetic capacity" ( $\left.A_{\text {max-canopy }}\right)$ and "canopy transpiration capacity" $\left.\left(E_{\text {canopy }}\right)\right]$.

$A_{\text {max-leaf }}$ and $E_{\text {leaf }}$ are extrapolated from gas exchange rates measured in the ideal environment within a controlled cuvette, and likely are higher than net photosynthesis and transpiration of a tree in naturally variable conditions (McGarvey et al. 2004). " $A_{\max }$ " is an idealized estimate of photosynthesis and " $E_{\text {leaf }}$ " is an idealized estimate of transpiration; the suffix leaf refers to the leaf-level rate of gas exchange per unit leaf area, while the suffixcanopy refers to estimates of the idealized canopy gas exchange. We therefore 
compare these approximations to estimate relative differences in gas exchange for trees in both BACI and factorial experiments, but they do not estimate the absolute effect of invasion on carbon fixation.

We measured pre-dawn $\left(\psi_{\mathbf{P D}}\right)$ and mid-day leaf water potential $\left(\psi_{\mathbf{M D}}\right)$ on the same day as the gas exchange measurements for each study site using a Model 610 Plant Pressure Chamber (PMS Instruments, Corvallis, OR). Treatment means ( \pm SEM) of $\psi_{\mathbf{P D}}$ and $\psi_{\mathbf{M D}}$ are in Tables S2 and S3. Wet season $\psi_{\mathbf{P D}}$ ranged from $c a$ . -1.0 to $-1.5 \mathrm{MPa}$ and dry season $\psi_{\mathbf{P D}}$ ranged fromca -1.9 to $-2.1 \mathrm{MPa}$; studies of related tree species in the region recorded $\psi_{\mathbf{P D}}$ of $c a$. -2.0 $\mathrm{MPa}$ in dry conditions (Gebrekirstos et al. 2006).

For each tree we calculated diurnal leaf water potential range ([?] $\left.\psi_{\text {leaf }}\right)$ as the difference between pre-dawn and mid-day leaf water potentials ([?] $\left.\psi_{\lambda \epsilon a \varphi}=\psi_{\Pi \Delta}-\psi_{M \Delta}\right)$. [?] $\psi_{\text {leaf }}$ demonstrates the range of viable water conditions that a leaf will experience (Gebrehiwot et al. 2005; Gebrekirstos et al.2006): that range is fundamentally created by stomatal water loss (Henryet al. 2019) and increased by loss of vascular hydraulic conductivity (Lambers et al. 2008; Scoffoni et al. 2017). Plants will often remain within a species-specific [?] $\psi_{\text {leaf }}$ (e.g., Gebrekirstos et al.2006), while photosynthesis and transpiration can vary without affecting [?] $\psi_{\text {leaf }}$ as a result of osmotic or stomatal adjustments (Inoue et al. 2017; Martínez-Vilalta \& Garcia-Forner 2017; Hochberg et al. 2018; Zhang et al.2019). Note S1 further describes tree physiology methods.

Statistical Analysis - We used generalized linear models (GLMs) to analyze data in the BACI and factorial experiments. For the BACI experiment, we constructed individual GLMs for each season (wet/dry) for $A_{\text {max-leaf }}, E_{\text {leaf }}$, and [?] $\psi_{\text {leaf }}$. In the BACI GLMs, sampling year $(2017,2018)$ and site type (Transition, Control) and their interaction term were fixed effects. We specifically report significant interaction terms for the BACI analysis results, to identify differences in leaf physiological traits for trees that were invaded between the 2017 and 2018 surveys, relative to interannual differences for the paired Control trees that experienced similar environmental conditions but no invasion. For the factorial experiment, we constructed separate GLMs for each season (wet/dry) for $A_{\text {max-canopy }}, E_{\text {canopy }}, A_{\text {max-leaf }}, E_{\text {leaf }}$, and [?] $\psi_{\text {leaf }}$. In the factorial experiment GLMs, ant identity (C. mimosae or P. megacephala) was a fixed effect, the exclusion of herbivores and ant occupants were fixed effects nested within ant occupant identity, and data from sampling periods were pooled. For both experiments, we also tested models that included site as a random effect, but this term was non-significant for all models and resulted in higher AICc scores, so we removed this term from our final analyses. Analyses were conducted using JMP Pro 14.1.0 (SAS Institute, Cary, North Carolina, USA). Further details on GLMs are in Note S2.

\section{Results}

Short-term effects of ant occupants and herbivores on A. drepanolobium physiology- In wet seasons, Control trees had lower $A_{\text {max-leaf }}$, lower $E_{\text {leaf }}$, and higher[?] $]_{\text {leaf }}$ in 2018 than in 2017, but Transition trees exhibited no significant differences in any of those traits $\left(A_{\text {max-leaf }}: \mathrm{F}_{1,131}=5.16, \mathrm{P}=0.0231\right.$, Fig. $1 \mathrm{~A} ; E_{\text {leaf }}: \mathrm{F}_{1,131}$ $=8.99, \mathrm{P}=0.0027$, Fig. $1 \mathrm{C} ;[?]_{\text {leaf }}: \mathrm{F}_{1,122}=3.88, \mathrm{P}=0.0488$; Fig. $\left.1 \mathrm{E}\right)$. During dry seasons, $A_{\text {max-leaf }}$ was substantially lower in 2018 than in 2017 for newly-invaded trees, while Control trees exhibited a significantly smaller interannual decline $\left(\mathrm{F}_{1,127}=17.78, \mathrm{P}<0.01\right.$; Fig. $\left.1 \mathrm{~B}\right) \cdot E_{\text {leaf }}$ was significantly higher for Control trees in 2018 than in 2017, while Transition trees remained consistent across years $\left(\mathrm{F}_{1,127}=4.53, \mathrm{P}=0.0332\right.$; Fig. 1D), trees at both sites exhibited consistent[?] $]_{\text {leaf }}$ in both years $\left(\mathrm{F}_{1,127}=0.00, \mathrm{P}=0.99\right.$; Fig. $\left.1 \mathrm{~F}\right)$.

Long-term effects of ant occupants and herbivores on Acacia drepanolobium physiology - Trees occupied by C. mimosae vs.P. megacephala in long-term Uninvaded and Invaded sites differed substantially in leaf water potential ranges, leaf gas exchange rates, and canopy gas exchange capacities. During wet seasons, trees in Invaded areas had reduced $A_{\text {max-leaf }}\left(\mathrm{F}_{1,205}=11.55, \mathrm{P}<0.001 ;\right.$ Fig. $\left.2 \mathrm{~A}\right), E_{\text {leaf }}\left(\mathrm{F}_{1,205}=15.68, \mathrm{P}<0.0001\right.$; Fig. S1A), $A_{\text {max-canopy }}\left(\mathrm{F}_{1,94}=42.33, \mathrm{P}<0.0001\right.$; Fig. $\left.2 \mathrm{~A}\right)$, and $E_{\text {canopy }}\left(\mathrm{F}_{1,94}=42.70, \mathrm{P}<0.0001\right.$; Fig. $\mathrm{S} 1 \mathrm{~A})$; however,[?] $]_{\text {leaf }}$ did not significantly vary $\left(\mathrm{F}_{1,193}=1.39, \mathrm{P}=0.24\right.$; Fig. S1C). During dry seasons, trees in Invaded areas had higher $A_{\text {max-leaf }}\left(\mathrm{F}_{1,212}=4.55, \mathrm{P}=0.0329\right.$; Fig. $\left.2 \mathrm{~B}\right)$ and $E_{\text {leaf }}\left(\mathrm{F}_{1,212}=5.96, \mathrm{P}<\right.$ 0.0001; Fig. S1B), but also slightly decreased[?] $]_{\text {leaf }}\left(\mathrm{F}_{1,208}=4.52, \mathrm{P}=0.0334\right.$; Fig. S1D) by $c a .0 .1 \mathrm{MPa}$; we did not find differences in $A_{\text {max-canopy }}\left(\mathrm{F}_{1,53}=0.06, \mathrm{P}=0.80\right.$; Fig. $\left.2 \mathrm{~B}\right)$ or $E_{\text {canopy }}\left(\mathrm{F}_{1,53}=0.49, \mathrm{P}=\right.$ 0.87; Fig. S1B) for long-term sites. 
During the rainy season, trees in Invaded areas that were exposed to vertebrate herbivores had lower $A_{\text {max-leaf }}\left(\mathrm{F}_{2,205}=5.03, \mathrm{P}=0.025 ;\right.$ Fig. $\left.3 \mathrm{~A}\right), A_{\text {max-canopy }}\left(\mathrm{F}_{2,94}=53.07, \mathrm{P}<0.0001 ;\right.$ Fig. $\left.3 \mathrm{C}\right)$, and $E_{\text {canopy }}$ $\left(\mathrm{F}_{2,94}=50.30, \mathrm{P}<0.0001 ;\right.$ Fig. $\left.4 \mathrm{~A}\right)$, and non-significantly lower $E_{\text {leaf }}\left(\mathrm{F}_{2,205}=2.99, \mathrm{P}=0.084 ;\right.$ Fig. $\left.\mathrm{S} 2 \mathrm{~A}\right) ;$ $[?]_{\text {leaf }}$ did not differ $\left(\mathrm{F}_{2,193}=0.20, \mathrm{P}=0.66\right)$. During the dry season, invaded trees in each herbivory treatment did not differ in $A_{\text {max-leaf }}\left(\mathrm{F}_{2,212}=1.94, \mathrm{P}=0.16\right.$; Fig. $\left.3 \mathrm{~B}\right), A_{\text {max-canopy }}\left(\mathrm{F}_{2,53}=1.71, \mathrm{P}=\right.$ 0.19; Fig. 3D), or[?] $]_{\text {leaf }}(\mathrm{P}=0.93$; Fig. 4D), but tree in Invaded areas that were exposed to vertebrates had slightly higher $E_{\text {leaf }}\left(\mathrm{F}_{2,212}=3.99, \mathrm{P}=0.0459\right.$; Fig $\left.\mathrm{S} 2 \mathrm{~B}\right)$ and $E_{\text {canopy }}\left(\mathrm{F}_{2,53}=5.70, \mathrm{P}=0.0189\right.$; Fig. $\left.4 \mathrm{~B}\right)$.

Through ant removal in our factorial experiment, we linked occurrence of $P$. megacephala ants with differences in water potential range and gas exchange in both wet and dry seasons. During wet seasons, Invaded trees that were experimentally cleared of $P$. megacephala had higher $A_{\text {max-canopy }}\left(\mathrm{F}_{2,94}=10.57, \mathrm{P}<0.001\right.$; Fig. $3 \mathrm{C})$ and $E_{\text {canopy }}\left(\mathrm{F}_{2,94}=10.77, \mathrm{P}<0.001 ; \mathrm{Fig} 3 \mathrm{~A}\right)$, and slightly smaller[?] $]_{\text {leaf }}\left(\mathrm{F}_{2,193}=4.32, \mathrm{P}=0.0378\right.$; Fig. $4 \mathrm{C})$ by $c a .0 .15 \mathrm{MPa}$; we did not find significant differences in $A_{\text {max-leaf }}\left(\mathrm{F}_{2,205}=0.19, \mathrm{P}=0.67\right.$; Fig. $3 \mathrm{~A})$ or $E_{\text {leaf }}\left(\mathrm{F}_{2,205}=0.07, \mathrm{P}=0.79\right.$; Fig. $\left.\mathrm{S} 2 \mathrm{~A}\right)$ on trees cleared of $P$. megacephala . In dry seasons, trees occupied by $P$. megacephala had slightly higher $E_{\text {leaf }}\left(\mathrm{F}_{2,212}=6.36, \mathrm{P}=0.0117\right.$; Fig $\left.\mathrm{S} 2 \mathrm{~B}\right)$ and $E_{\text {canopy }}$ $\left(\mathrm{F}_{2,53}=8.38, \mathrm{P}=0.0038\right.$; Fig. $\left.4 \mathrm{~B}\right)$ than $P$. megacephala removal trees, but we found no differences between these treatments in $A_{\text {max-leaf }}\left(\mathrm{F}_{2,212}=0.01, \mathrm{P}=0.92\right.$; Fig. $\left.3 \mathrm{~B}\right), A_{\text {max-canopy }}\left(\mathrm{F}_{2,53}=3.11, \mathrm{P}=0.08\right.$; Fig. $3 \mathrm{D})$, or $[?]_{\text {leaf }}\left(\mathrm{F}_{2,208}=2.57, \mathrm{P}=0.11\right.$; Fig. $\left.4 \mathrm{D}\right)$. In contrast to trees from long-term Invaded sites, trees occupied by C. mimosaeat Uninvaded sites did not exhibit different gas exchange or leaf water potential traits due to ant removal, herbivore exclusion or their interaction (Note S3).

\section{Discussion}

Pheidole megacephala invasion strongly influenced rates of carbon fixation in A. drepanolobium, consistent with other studies demonstrating that invasive species can alter fundamental ecosystem processes (Hooper $e t$ al. 2005; Morales et al. 2017). These long-term negative effects of $P$. megacephala on carbon fixation, despite an initial positive effect of invasion on leaf carbon fixation rates, highlight that some ecologically relevant effects of invasive species can lag behind their initial appearance in a habitat (Crooks 2005; Simberloff 2011). The change in sign of the net effect of $P$. megacephala on host tree carbon fixation across different temporal scales illuminates the value of long-term studies examining the effects of invasive species on ecosystem processes (sensu Strayer et al.2006).

Our results from Transition sites suggest that $P$. megacephalatriggers short-term benefits for newly invaded trees, which may enable newly invaded trees to maintain similar wet season photosynthetic rates before and immediately after invasion, despite a decline of photosynthetic rates in their neighboring control trees in that same time period. The loss of nectivorous mutualists in recently invaded areas likely removes a carbohydrate sink for A. drepanolobium(Stanton \& Palmer 2011), freeing resources to support leaf growth, photosynthetic upregulation, and other metabolic processes (Wiley \& Helliker 2012; Glanz-Idan \& Wolf 2020). Increased carbohydrate availability may support costly molecular and biochemical mechanisms that mitigate heat-related damage to photosynthetic apparatuses (Mathuret al. 2014). High maximum daily temperatures $\left(28-31^{\circ} \mathrm{C}\right)$, which can cause substantial interannual changes in phenology of other deciduous tree species (e.g., Muraoka et al. 2010) were recorded in the January-March dry season that occurred between 2017 and 2018 wet season measurements (Caylor et al. 2020). This may explain why Control trees showed a large interannual decline in photosynthetic rates, while Transition trees had consistent photosynthetic rates in 2017 (before invasion) and 2018 (after invasion). These benefits of invasion were apparently negated in the subsequent drought period, perhaps because mixed feeders that forage on woody species during the dry season (Illius \& O'Connor 1999) began to target invaded trees. These results suggest that maintenance of photosynthesis may only be a sustainable strategy to support growth under low intensity herbivory (sensu Gadd et al. 2001) in favorable abiotic conditions.

Contrasting with short-term results, we found that A. drepanolobium had markedly lower canopy photosynthetic capacity in long-term Invaded areas vs. Uninvaded areas. In savannas that have been invaded for $>$ 5 years, a 2-meter-tall tree has a canopy photosynthetic capacity of only $c a .31 \%$ of the carbon fixation per hour as a comparable uninvaded tree during the wet season, a primary growing period for many African 
acacias (Gourlay 1995). This difference is partially driven by leaf photosynthetic rates that are ca.13\% lower during the wet season for invaded trees, but is greatly magnified by canopy leaf areas that are $c a .65 \%$ lower for trees in long-term Invaded areas. The P. megacephala -driven decline in photosynthetic capacity for invaded A. drepanolobium is similar in magnitude to declines in photosynthesis in North American hardwood forests subjected to defoliation by non-native insects (Kurz et al. 2008; Albani et al. 2010; Clark et al. 2010).

Results from our herbivore and ant exclusion experiment suggest that vertebrate herbivory is the primary driver of changes in the leaf and canopy photosynthesis and transpiration for trees in Invaded habitats. Large herbivores, particularly elephants, suppress the canopy size of many woody plants in Sub-Saharan Africa (Pellew 1983; Biggs \& Jacobs 2002; Goheen \& Palmer 2010), and King and Caylor (2010) showed that large herbivores can suppress leaf photosynthetic rates for A. drepanolobium trees when occupied by a native ant (Crematogaster sjostedti ) that ineffectively repels herbivores (Martins 2010). Our results similarly show that $P$. megacephala invasion triggers large changes in leaf and canopy photosynthetic capacity when co-occurring with large herbivores. Reduced leaf area in invaded trees is the strongest driver of canopy photosynthesis decline, but herbivores can also induce changes to leaf structure and function in invaded areas. For example, A. drepanolobium occupied by less defensive native mutualists increase leaf phenol concentrations in $c a$. 1-m-tall branches in response to herbivory (Ward \& Young 2002), which could be occurring on invaded trees at our study sites as well. The tradeoff between leaf phenolic concentrations and photosynthetic rates is well conserved (e.g., Ishida et al. 2008; Sumbele et al. 2012) and plastic (e.g., Keenan \& Niinemets 2016 and references therein) across plant species, and so we may expect to see similar changes in photosynthetic rates for other plants that experience intense herbivory after ant invasion.

The occurrence of invasive ants in long-term invaded trees directly impacted leaf physiology, though to a lesser degree than the occurrence of large herbivores in invaded areas. This may be driven by root damage by nesting workers or through facultative interactions with other insect pests in the canopy. While we did not explicitly examine these relationships here, P. megacephala tends lycaenid caterpillars (pers. observation T. Palmer; a widespread association in Australia, Eastwood \& Fraser 1999) and appeared to tolerate cerambycid larvae infestations (pers. observation P. Milligan) in the canopy. Infestations of phloem-feeding insects can affect photosynthetic rates and water use efficiency of many plant taxa (Cockfield et al. 1987; Meyer \& Whitlow 1992; Haavik et al. 2008; Golan et al. 2015). We did not quantify the size of $P$. megacephala nests around tree roots in this field experiment, but the excavation of nest cavities around roots has been observed in A. drepanolobium saplings (Milligan et al. in preparation). Moreover, resource-limited invaded trees may also produce fewer fine root hairs (a key factor for water uptake in clay dominated soils, Lambers et al . 2008 ) or reduce the production and activation of water channels in cell membranes (e.g., aquaporins). Nesting by invasive ants near can affect plant water status and soil water content (Moutinho et al. 2003), and water status influences photosynthesis, transpiration, and solute management of other African acacias (Szarek \& Woodhouse 1978; Kebbas et al.2015). Thus, the simple process of nest excavation around plant roots may enable invasive ants to affect host plant physiology in this and other systems.

Leaf and canopy gas exchange differed between long-term invaded and uninvaded trees but leaf water potential ranges did not, which altogether may be attributable to differences in leaf water management.Acacia drepanolobium in long-term invaded habitats may close stomata to minimize water loss, which could result in similar leaf water potential ranges at a cost to photosynthesis (Farquhar \& Sharkey 1982). Additionally, A. drepanolobium in Uninvaded habitats may have more carbohydrates to support the management of solute concentrations in leaves, which can allow high gas exchanges rates and capacities without inducing a change in leaf water potential range (Inoue et al.2017; Zhang et al. 2019). These osmotic adjustments can be metabolically costly but would also allow large increases in carbon fixation, and thus may create net photosynthetic benefits at the canopy level for uninvaded trees. These proposed mechanisms occur in tissues that can have high turnover in acacias (Jha \& Mohapatra 2010) and so may be reversible if herbivore pressure is reduced. Recent climate change models predict that the East African region will shift to wetter climates with less severe droughts over the next century (Shongweet al. 2011; Haile et al. 2020), and physiological adjustments by $A$. drepanolobium to these climatic changes may differ in invaded and uninvaded savannas. 
Both herbivore exclusion and $P$. megacephala removal positively impacted host tree physiology in invaded habitats, but we did not find a positive effect of herbivore exclusion or a negative effect of $C$. mimosae removal in uninvaded habitats. These effects would be expected, because $C$. mimosae strongly repels herbivores that can reduce tree performance. The mechanisms underlying this pattern are not clear, but one potential explanation relates to the idea of "associational defense" (Barbosa et al. 2009), where plants with weak defenses gain protection by proximity to well-defended neighbors. Our C. mimosae-removal trees in unfenced areas were typically adjacent $(c a .5 \mathrm{~m})$ to well-defended $A$. drepanolobium trees occupied by mature colonies of defensive ants, which may have reduced browsing on removal plants to comparable levels seen both on $C$. mimosae -occupied plants in open areas, and host plants within herbivore exclosures. Coverdale et al. (2018) found evidence for associational defenses at another Laikipia conservancy between other Acacia species that deploy inducible defense (i.e. spines) and their understory plant neighbors, though our study suggests that the same principle applies to ant-defended trees and their conspecific neighbors.

Our study demonstrates how an invasive ant can interact with vertebrate herbivores to limit carbon fixation, and in turn contribute to a carbon "deficit" in a foundational plant. Such deficits have been shown to initiate plant performance declines in many systems. For example, both McDowell (2011) and Wiley and Helliker (2012) discuss the process of carbon starvation, where plant mortality rises due to large declines in carbon fixation or strong increases in metabolic costs. Allen et al. (2010) primarily attribute observed contemporary global increases in plant mortality to climatic shifts, while McDowell (2011) describes how invasive insects can increase mortality before the tree has even exhausted its resources. As demonstrated in this study, invasive insects can also strongly affect carbon fixation via system-specific interactions with vertebrate herbivores that may be difficult to generalize for broad carbon starvation hypotheses.

Some aspects of our observed decline in carbon fixation are context-specific, but others are clearly paralleled in other systems. In dry conditions, herbivores are often more selective for high quality forage both in this system (Veblen 2008) and other savannas (e.g., Roques et al. 2001; Kos et al. 2012; Abraham et al.2019), and herbivory thus becomes frequent and intense for plants like A. drepanolobium with leaves containing high amounts of crude protein and minerals (Rubanza et al. 2007). Chronic herbivory imposes cumulative respiration costs for both undefended A. drepanolobium (regrowing lost foliage, Gadd et al. 2001; producing defense metabolites, Ward \& Young 2002) and for plants in many other systems (e.g., Kozlov \& Zvereva 2017; Wilson et al.2018). Inducible responses to herbivory (osmotic adjustment, Freelandet al. 1985; tannin/saponin production, Sharpe et al.1986; spine production, Young \& Okello 1998) can consume a large portion of the tree's carbohydrate budget and contribute to a decline in photosynthetic rates (as well as metabolism, regeneration, and chemical defense; reviewed by Wiley \& Helliker 2012).

Our results also contribute to our understanding of the A. drepanolobium -ant model mutualism and antplant mutualisms more broadly. The results from our recently invaded Transition sites support the argument that ant-plants prioritize resources for ant symbionts despite the cost of these allocation decisions for other biological processes. Ant mutualists may impose costs to host plants in a variety of ways, including consuming plant-provisioned food bodies (O'Dowd 1980; Heil et al. 1997; Stanton \& Palmer 2011), disrupting pollinator visitation (Ness 2006; Villamil et al. 2020), or causing floral castration (Stanton et al. 1999; Gaume et al. 2005). However, ant-plant partnerships typically yield long-term net benefits for the plant by reducing herbivore damage (Chamberlain \& Holland 2009) or even increasing competitiveness against other plants (Fiala et al. 1989). Our study adds to this literature, demonstrating that native ant associates impose significant metabolic costs to host plants, while yielding positive net effects on photosynthesis across longer time scales owing to effective herbivore protection.

The long-term loss of photosynthetic capacity for ant-plants in invaded habitat reduces A. drepanolobium 's carbohydrate pool, which may affect other ecosystem processes to which this foundational tree contributes. For example, nitrogen is a limiting resource for plant productivity in black cotton savannas, and A. drepanolobiumimports nitrogen into these systems through N-fixation (Fox-Dobbset al. 2010). If host plants must reduce their photosynthate allocation to roots in invaded habitats, this could in turn reduce both N-fixing symbiont activity and soil respiration, similar to effects seen in a large-scale girdling experiment in a boreal 
forest by Högberget al. (2001). Potentially compounding this effect, elephants may reduce tree cover within invaded savannas over the longer term, further reducing $\mathrm{N}$ inputs into the system, as has been shown in other areas of East Africa where removal of acacia species reduces both the total content and mineralization of $\mathrm{C}$ and $\mathrm{N}$ in soils (Glaser et al.2001). Finally, Acacia drepanolobium has density-dependent effects on the productivity of understory plants (Riginos et al.2009), and thus the carbon fixation performance of invaded trees may also be linked to understory productivity. By increasing the mortality (Riginos et al. 2015) and decreasing the performance of this monodominant tree species, $P$. megacephala invasion may fundamentally alter carbon cycling and connected ecosystem processes in these savannas.

Acknowledgements: We thank the Kenyan government (NACOSTI/P/18/4376/9459) for their permission to conduct this work. Gabriella Mizell, Nelly Maiyo, Jackson Ekadeli, Gilbert Buseinei, Isaac Kipkoech, and John Lemosiany provided excellent field assistance. Mpala Research Centre administration and the Ol Pejeta Conservancy management team (particularly Samuel Mutisya and Benard Gituku) provided substantial logistical support. This research was supported by a University of Florida International Center RADS grant to PDM, a Smithsonian ForestGeo grant to PDM, a National Geographic Society Young Explorer grant to PDM, and a National Science Foundation grant (NSF DEB 1556905) to TMP, CR and JRG.

\section{Literature Cited}

1.

Abraham, J.O., Hempson, G.P. \& Staver, A.C. (2019). Drought-response strategies of savanna herbivores. Ecology and evolution, 9, 7047-7056.

2 .

Albani, M., Moorcroft, P.R., Ellison, A.M., Orwig, D.A. \& Foster, D.R. (2010). Predicting the impact of hemlock woolly adelgid on carbon dynamics of eastern United States forests. Canadian Journal of Forest Research , 40, 119-133.

3.

Allen, C.D., Macalady, A.K., Chenchouni, H., Bachelet, D., McDowell, N., Vennetier, M. et al. (2010). A global overview of drought and heat-induced tree mortality reveals emerging climate change risks for forests. Forest ecology and management, 259, 660-684.

4.

Anastasio, O.E. (2020). Impacts of invasive ant-hemipteran interaction, edge effects and habitat complexities on the spatial distribution of ants. Clark University.

5.

Beardsley, J.W., Su, T.H., McEwen, F. \& Gerling, D. (1982). Field investigations on the interrelationships of the big-headed ant, the gray pineapple mealybug, and pineapple mealybug wilt disease in Hawaii.

6.

Bertelsmeier, C., Ollier, S., Liebhold, A. \& Keller, L. (2017). Recent human history governs global ant invasion dynamics. Nature Ecology $\& 3$ Evolution, 1, 0184.

7.

Biggs, R. \& Jacobs, O. (2002). The impact of the African elephant on marula trees in the Kruger National Park. South African Journal of Wildlife Research-24-month delayed open access, 32, 13-22.

8.

Bradshaw, C.J., Leroy, B., Bellard, C., Roiz, D., Albert, C., Fournier, A. et al. (2016). Massive yet grossly underestimated global costs of invasive insects. Nature communications , 7, 1-8. 
9.

Caylor, K.K., Gitonga, J. \& Martins, D.J. (2020). Mpala Research Centre Meteorological and Hydrological Dataset. Summary Weather data 2018-2020, Laikipia, Kenya. Mpala Research Centre.

10.

Chamberlain, S.A. \& Holland, J.N. (2009). Quantitative synthesis of context dependency in ant-plant protection mutualisms. Ecology, 90, 2384-2392.

11.

Clark, K.L., Skowronski, N. \& Hom, J. (2010). Invasive insects impact forest carbon dynamics. Global Change Biology , 16, 88-101.

12.

Cockfield, S.D., Potter, D.A. \& Houtz, R.L. (1987). Chlorosis and reduced photosynthetic CO2 assimilation of Euonymus fortunei infested with euonymus scale (Homoptera: Diaspididae). Environmental entomology , 16, 1314-1318.

13.

Coverdale, T.C., Goheen, J.R., Palmer, T.M. \& Pringle, R.M. (2018). Good neighbors make good defenses: associational refuges reduce defense investment in African savanna plants. Ecology, 99, 1724-1736.

14.

Crooks, J.A. (2005). Lag times and exotic species: The ecology and management of biological invasions in slow-motion. Ecoscience, 12, 316-329.

15.

Del-Claro, K., Rico-Gray, V., Torezan-Silingardi, H.M., Alves-Silva, E., Fagundes, R., Lange, D. et al. (2016). Loss and gains in ant-plant interactions mediated by extrafloral nectar: fidelity, cheats, and lies. Insectes Sociaux, 63, 207-221.

16.

Demian, N. \& Tarnita, C.E. (2019). Ant-plant-hemipteran interactions between non-native species in Laikipia, Kenya. In: Ecology and Evolutionary Biology . Princeton University.

17.

Eastwood, R. \& Fraser, A.M. (1999). Associations between lycaenid butterflies and ants in Australia. Australian Journal of Ecology, 24, 503-537.

18.

Englund, R.A. (2008). Invasive species threats to native aquatic insect biodiversity and conservation measures in Hawai'i and French Polynesia. In: Insect Conservation and Islands . Springer, pp. 221-234.

19.

Farquhar, G.D. \& Sharkey, T.D. (1982). Stomatal conductance and photosynthesis. Annual review of plant physiology, 33, 317-345.

20.

Fiala, B., Maschwitz, U., Pong, T.Y. \& Helbig, A.J. (1989). Studies of a South East Asian ant-plant association: protection of Macaranga trees by Crematogaster borneensis. Oecologia , 79, 463-470.

21. 
Finer, L., Jurgensen, M.F., Domisch, T., Kilpelainen, J., Neuvonen, S., Punttila, P. et al. (2013). The role of wood ants (Formica rufa group) in carbon and nutrient dynamics of a boreal Norway spruce forest ecosystem. Ecosystems , 16, 196-208.

22.

Fox-Dobbs, K., Doak, D.F., Brody, A.K. \& Palmer, T.M. (2010). Termites create spatial structure and govern ecosystem function by affecting N-2 fixation in an East African savanna. Ecology, 91, 1296-1307.

23.

Frederickson, M.E., Greene, M.J. \& Gordon, D.M. (2005). 'Devil's gardens' bedevilled by ants. Nature , $437,495-496$.

24.

Freeland, W.J., Calcott, P. \& Anderson, L.R. (1985). Tannins and saponin: interaction in herbivore diets. Biochemical Systematics and Ecology, 13, 189-193.

25.

Fuster, F., Kaiser-Bunbury, C.N. \& Traveset, A. (2020). Pollination effectiveness of specialist and opportunistic nectar feeders influenced by invasive alien ants in the Seychelles. American Journal of Botany

26.

Gadd, M.E., Young, T.P. \& Palmer, T.M. (2001). Effects of simulated shoot and leaf herbivory on vegetative growth and plant defense in Acacia drepanolobium. Oikos , 92, 515-521.

27.

Gaigher, R., Samways, M.J. \& Van Noort, S. (2013). Saving a tropical ecosystem from a destructive antscale (Pheidole megacephala, Pulvinaria urbicola) mutualism with support from a diverse natural enemy assemblage. Biological Invasions, 15, 2115-2125.

28.

Gandhi, K.J. \& Herms, D.A. (2010). Direct and indirect effects of alien insect herbivores on ecological processes and interactions in forests of eastern North America. Biological Invasions, 12, 389-405.

29.

Gaume, L., Zacharias, M. \& Borges, R.M. (2005). Ant-plant conflicts and a novel case of castration parasitism in a myrmecophyte.Evolutionary Ecology Research , 7, 435-452.

30.

Gebrehiwot, K., Muys, B., Haile, M. \& Mitloehner, R. (2005). The use of plant water relations to characterize tree species and sites in the drylands of northern Ethiopia. Journal of Arid Environments , 60, 581-592.

31.

Gebrekirstos, A., Teketay, D., Fetene, M. \& Mitlohner, R. (2006). Adaptation of five co-occurring tree and shrub species to water stress and its implication in restoration of degraded lands. Forest Ecology and Management , 229, 259-267.

32.

Glanz-Idan, N. \& Wolf, S. (2020). Upregulation of photosynthesis in mineral nutrition-deficient tomato plants by reduced source-to-sink ratio. Plant Signal Behav , 15, 1712543.

33. 
Glaser, B., Lehmann, J., Fuhrboter, M., Solomon, D. \& Zech, W. (2001). Carbon and nitrogen mineralization in cultivated and natural savanna soils of Northern Tanzania. Biology and fertility of soils , 33, 301-309.

34.

Goheen, J.R. \& Palmer, T.M. (2010). Defensive plant-ants stabilize megaherbivore-driven landscape change in an African savanna. Current Biology , 20, 1768-1772.

35.

Golan, K., Rubinowska, K., Kmieć, K., Kot, I., Górska-Drabik, E., Łagowska, B. et al. (2015). Impact of scale insect infestation on the content of photosynthetic pigments and chlorophyll fluorescence in two host plant species. Arthropod-Plant Interactions , 9, 55-65.

36.

Goldschmidt, E.E. \& Huber, S.C. (1992). Regulation of Photosynthesis by End-Product Accumulation in Leaves of Plants Storing Starch, Sucrose, and Hexose Sugars. Plant Physiology, 99, 1443-1448.

37.

Gourlay, I.D. (1995). Growth ring characteristics of some African Acacia species. Journal of tropical ecology , 121-140.

38.

Haavik, L., Stephen, F., Fierke, M., Salisbury, V., Leavitt, S. \& Billings, S. (2008). Dendrochronological parameters of northern red oak (Quercus rubra L.(Fagaceae)) infested with red oak borer (Enaphalodes rufulus (Haldeman)(Coleoptera: Cerambycidae)). Forest Ecology and Management, 255, 1501-1509.

39.

Haile, G.G., Tang, Q., Hosseini-Moghari, S.M., Liu, X., Gebremicael, T., Leng, G. et al. (2020). Projected impacts of climate change on drought patterns over East Africa. Earth's Future, 8, e2020EF001502.

40.

Heil, M., Fiala, B., Linsenmair, K.E., Zotz, G. \& Menke, P. (1997). Food body production in Macaranga triloba (Euphorbiaceae): a plant investment in anti-herbivore defence via symbiotic ant partners. Journal of Ecology , 847-861.

41.

Henry, C., John, G.P., Pan, R., Bartlett, M.K., Fletcher, L.R., Scoffoni, C. et al. (2019). A stomatal safety-efficiency trade-off constrains responses to leaf dehydration. Nature communications, 10, 1-9.

42.

Hill, J.K., Rosengaus, R.B., Gilbert, F.S. \& Hart, A.G. (2013). Invasive ants-are fire ants drivers of biodiversity loss.Ecological Entomology, 38, 539-539.

43.

Hochberg, U., Rockwell, F.E., Holbrook, N.M. \& Cochard, H. (2018). Iso/anisohydry: a plant-environment interaction rather than a simple hydraulic trait. Trends in Plant Science , 23, 112-120.

44.

Hoffmann, B.D. \& Parr, C.L. (2008). An invasion revisited: the African big-headed ant (Pheidole megacephala) in northern Australia.Biological invasions , 10, 1171-1181.

45. 
Högberg, P., Nordgren, A., Buchmann, N., Taylor, A.F.S., Ekblad, A., Högberg, M.N. et al. (2001). Largescale forest girdling shows that current photosynthesis drives soil respiration. Nature, 411, 789-792.

46.

Holway, D.A., Lach, L., Suarez, A.V., Tsutsui, N.D. \& Case, T.J. (2002). The causes and consequences of ant invasions. Annual review of ecology and systematics , 33, 181-233.

47.

Hooper, D.U., Chapin, F.S., Ewel, J.J., Hector, A., Inchausti, P., Lavorel, S. et al. (2005). Effects of biodiversity on ecosystem functioning: A consensus of current knowledge. Ecological Monographs , 75, 3-35.

48.

Horvitz, C.C. \& Schemske, D.W. (1986). Seed dispersal of a neotropical myrmecochore: variation in removal rates and dispersal distance.Biotropica, 319-323.

49.

Huntzinger, M., Karban, R., Young, T.P. \& Palmer, T.M. (2004). Relaxation of induced indirect defenses of acacias following exclusion of mammalian herbivores. Ecology , 85, 609-614.

50.

Illius, A.W. \& O'Connor, T.G. (1999). On the relevance of nonequilibrium concepts to arid and semiarid grazing systems.Ecological applications , 9, 798-813.

51.

Inoue, Y., Ichie, T., Kenzo, T., Yoneyama, A., Kumagai, T.o. \& Nakashizuka, T. (2017). Effects of rainfall exclusion on leaf gas exchange traits and osmotic adjustment in mature canopy trees of Dryobalanops aromatica (Dipterocarpaceae) in a Malaysian tropical rain forest. Tree Physiology , 37, 1301-1311.

52.

Ishida, A., Nakano, T., Yazaki, K., Matsuki, S., Koike, N., Lauenstein, D.L. et al. (2008). Coordination between leaf and stem traits related to leaf carbon gain and hydraulics across 32 drought-tolerant angiosperms. Oecologia , 156, 193.

53.

Jha, P. \& Mohapatra, K.P. (2010). Leaf litterfall, fine root production and turnover in four major tree species of the semi-arid region of India. Plant and Soil , 326, 481-491.

54.

Kebbas, S., Lutts, S. \& Aid, F. (2015). Effect of drought stress on the photosynthesis of Acacia tortilis subsp. raddiana at the young seedling stage. Photosynthetica, 53, 288-298.

55.

Keenan, T.F. \& Niinemets, Ü. (2016). Global leaf trait estimates biased due to plasticity in the shade. Nature Plants , 3, 16201 .

56.

King, E.G. \& Caylor, K.K. (2010). Herbivores and mutualistic ants interact to modify tree photosynthesis. The New phytologist, 187, 17-21.

57. 
Kos, M., Hoetmer, A.J., Pretorius, Y., de Boer, W.F., de Knegt, H., Grant, C. et al. (2012). Seasonal diet changes in elephant and impala in mopane woodland. European journal of wildlife research , 58, 279-287.

58.

Kozlov, M.V. \& Zvereva, E.L. (2017). Background insect herbivory: impacts, patterns and methodology. In: Progress in Botany Vol. 79 . Springer, pp. 313-355.

59.

Kulikowski II, A.J. (2020). Ant-scale mutualism increases scale infestation, decreases folivory, and disrupts biological control in restored tropical forests. Biotropica, 52, 709-716.

60.

Kurz, W.A., Dymond, C.C., Stinson, G., Rampley, G.J., Neilson, E.T., Carroll, A.L. et al. (2008). Mountain pine beetle and forest carbon feedback to climate change. Nature, 452, 987-990.

61.

Lach, L., Hobbs, R.J. \& Majer, J.D. (2009). Herbivory-induced extrafloral nectar increases native and invasive ant worker survival.Population Ecology, 51, 237-243.

62.

Lach, L. \& Hoffmann, B.D. (2011). Are invasive ants better plant-defense mutualists? A comparison of foliage patrolling and herbivory in sites with invasive yellow crazy ants and native weaver ants. Oikos , 120, $9-16$.

63.

Lambers, H., Chapin III, F.S. \& Pons, T.L. (2008). Plant physiological ecology . Springer Science \& Business Media.

64.

Martinez-Vilalta, J. \& Garcia-Forner, N. (2017). Water potential regulation, stomatal behaviour and hydraulic transport under drought: deconstructing the iso/anisohydric concept. Plant, Cell \& Environment, 40, 962-976.

65.

Martins, D.J. (2010). Not all ants are equal: obligate acacia ants provide different levels of protection against mega-herbivores. African Journal of Ecology , 48, 1115-1122.

66.

Mathur, S., Agrawal, D. \& Jajoo, A. (2014). Photosynthesis: response to high temperature stress. Journal of Photochemistry and Photobiology B: Biology, 137, 116-126.

67.

McDowell, N.G. (2011). Mechanisms Linking Drought, Hydraulics, Carbon Metabolism, and Vegetation Mortality. Plant Physiology , 155, 1051-1059.

68.

McGarvey, R.C., Martin, T.A. \& White, T.L. (2004). Integrating within-crown variation in net photosynthesis in loblolly and slash pine families. Tree Physiology , 24, 1209-1220.

69. 
McGeoch, M.A., Lythe, M.J., Henriksen, M.V. \& McGrannachan, C.M. (2015). Environmental impact classification for alien insects: a review of mechanisms and their biodiversity outcomes. Current Opinion in Insect Science, 12, 46-53.

70.

Meyer, G.A. \& Whitlow, T.H. (1992). Effects of leaf and sap feeding insects on photosynthetic rates of goldenrod. Oecologia , 92, 480-489.

71.

Milligan, P.D., Prior, K.M. \& Palmer, T.M. (2016). An invasive ant reduces diversity but does not disrupt a key ecosystem function in an African savanna. Ecosphere, 7, e01502.

72.

Morales, C.L., Saez, A., Garibaldi, L.A. \& Aizen, M.A. (2017). Disruption of pollination services by invasive pollinator species. In:Impact of biological invasions on ecosystem services . Springer, pp. 203-220.

73.

Moutinho, P., Nepstad, D. \& Davidson, E. (2003). Influence of leaf-cutting ant nests on secondary forest growth and soil properties in Amazonia. Ecology , 84, 1265-1276.

74.

Muraoka, H., Saigusa, N., Nasahara, K.N., Noda, H., Yoshino, J., Saitoh, T.M. et al. (2010). Effects of seasonal and interannual variations in leaf photosynthesis and canopy leaf area index on gross primary production of a cool-temperate deciduous broadleaf forest in Takayama, Japan. Journal of Plant Research , $123,563-576$.

75.

Nebauer, S.G., Renau-Morata, B., Guardiola, J.L. \& Molina, R.-V. (2011). Photosynthesis down-regulation precedes carbohydrate accumulation under sink limitation in Citrus. Tree Physiology, 31, 169-177.

76.

Ness, J. \& Bronstein, J.L. (2004). The effects of invasive ants on prospective ant mutualists. Biological Invasions , 6, 445-461.

77.

Ness, J.H. (2006). A mutualism's indirect costs: the most aggressive plant bodyguards also deter pollinators. Oikos , 113, 506-514.

78.

O'Dowd, D.J. (1980). Pearl bodies of a neotropical tree, Ochroma pyramidale: ecological implications. American Journal of Botany, 67, 543-549.

79.

Paini, D.R., Sheppard, A.W., Cook, D.C., De Barro, P.J., Worner, S.P. \& Thomas, M.B. (2016). Global threat to agriculture from invasive species.Proceedings of the National Academy of Sciences, 113, 7575-7579.

80.

Palmer, T.M. (2004). Wars of attrition: colony size determines competitive outcomes in a guild of African acacia ants. Animal Behaviour, 68, 993-1004.

81. 
Pellew, R.A.P. (1983). The impacts of elephant, giraffe and fire upon the Acacia tortilis woodlands of the Serengeti. African Journal of Ecology, 21, 41-74.

82.

Pimentel, D., McNair, S., Janecka, J., Wightman, J., Simmonds, C., O'connell, C. et al. (2001). Economic and environmental threats of alien plant, animal, and microbe invasions. Agriculture, ecosystems $\mathcal{E}$ environment, 84, 1-20.

83.

Pringle, E.G. (2016). Integrating plant carbon dynamics with mutualism ecology. New Phytologist , 210, 71-75.

84.

Prior, K.M. \& Palmer, T.M. (2018). Economy of scale: third partner strengthens a keystone ant-plant mutualism. Ecology, 99, 335-346.

85.

Riginos, C., Grace, J.B., Augustine, D.J. \& Young, T.P. (2009). Local versus landscape-scale effects of savanna trees on grasses. Journal of Ecology, 97, 1337-1345.

86.

Riginos, C., Karande, M.A., Rubenstein, D.I. \& Palmer, T.M. (2015). Disruption of a protective ant-plant mutualism by an invasive ant increases elephant damage to savanna trees. Ecology , 96, 654-661.

87.

Risch, A.C., Jurgensen, M.F., Schutz, M. \& Page-Dumroese, D.S. (2005). The contribution of red wood ants to soil $\mathrm{C}$ and $\mathrm{N}$ pools and $\mathrm{CO} 2$ emissions in subalpine forests. Ecology , 86, 419-430.

88.

Rodriguez-Cabal, M.A., Stuble, K.L., Guenard, B., Dunn, R.R. \& Sanders, N.J. (2012). Disruption of antseed dispersal mutualisms by the invasive Asian needle ant (Pachycondyla chinensis). Biological Invasions , $14,557-565$.

89.

Roques, K.G., O'Connor, T.G. \& Watkinson, A.R. (2001). Dynamics of shrub encroachment in an African savanna: relative influences of fire, herbivory, rainfall and density dependence. Journal of Applied Ecology , $38,268-280$.

90.

Rubanza, C.D., Shem, M.N., Bakengesa, S.S., Ichinohe, T. \& Fujihara, T. (2007). The content of protein, fibre and minerals of leaves of selected Acacia species indigenous to north-western Tanzania. Archives of animal nutrition, 61, 151-156.

91.

Savage, A.M., Rudgers, J.A. \& Whitney, K.D. (2009). Elevated dominance of extrafloral nectary-bearing plants is associated with increased abundances of an invasive ant and reduced native ant richness.Diversity and Distributions , 15, 751-761.

92.

Scoffoni, C., Sack, L. \& Ort, D. (2017). The causes and consequences of leaf hydraulic decline with dehydration. Journal of Experimental Botany , 68, 4479-4496. 
93.

Sharpe, P., Newton, R. \& Spence, R. (1986). Forest pests: the role of phloem osmotic adjustment in the defensive response of conifers to bark beetle attack. In: Stress physiology and forest productivity . Springer, pp. 113-131.

94.

Shongwe, M.E., van Oldenborgh, G.J., van den Hurk, B. \& van Aalst, M. (2011). Projected changes in mean and extreme precipitation in Africa under global warming. Part II: East Africa. Journal of climate, 24, 3718-3733.

95.

Simberloff, D. (2011). How common are invasion-induced ecosystem impacts? Biological invasions , 13, $1255-1268$.

96.

Stanton, M.L. \& Palmer, T.M. (2011). The high cost of mutualism: effects of four species of East African ant symbionts on their myrmecophyte host tree. Ecology, 92, 1073-1082.

97.

Stanton, M.L., Palmer, T.M., Young, T.P., Evans, A. \& Turner, M.L. (1999). Sterilization and canopy modification of a swollen thorn acacia tree by a plant-ant. Nature, 401, 578-581.

98.

Strayer, D.L., Eviner, V.T., Jeschke, J.M. \& Pace, M.L. (2006). Understanding the long-term effects of species invasions. Trends in ecology $\& 3$ evolution, 21, 645-651.

99.

Sumbele, S., Fotelli, M.N., Nikolopoulos, D., Tooulakou, G., Liakoura, V., Liakopoulos, G. et al. (2012). Photosynthetic capacity is negatively correlated with the concentration of leaf phenolic compounds across a range of different species. AoB Plants, 2012.

100.

Szarek, S. \& Woodhouse, R. (1978). Ecophysiological studies of Sonoran Desert plants. IV. Seasonal photosynthetic capacities of Acacia greggii and Cercidium microphyllum. Oecologia , 221-229.

101.

Vanbergen, A.J., Espindola, A. \& Aizen, M.A. (2018). Risks to pollinators and pollination from invasive alien species. Nature Ecology \& Evolution , 2, 16-25.

102.

Veblen, K.E. (2008). Season-and herbivore-dependent competition and facilitation in a semiarid savanna. Ecology, 89, 1532-1540.

103.

Villamil, N., Boege, K. \& Stone, G.N. (2020). Ant guards influence the mating system of their plant hosts by altering pollinator behaviour.bioRxiv , 2020.2002.2011.943431.

104.

Ward, D. \& Young, T.P. (2002). Effects of large mammalian herbivores and ant symbionts on condensed tannins of Acacia drepanolobium in Kenya.Journal of Chemical Ecology , 28, 921-937. 
105.

Wetterer, J.K. (2012). Worldwide spread of the African big-headed ant, Pheidole megacephala (Hymenoptera: Formicidae). Myrmecological News , 17, 51-62.

106.

Wiley, E. \& Helliker, B. (2012). A re-evaluation of carbon storage in trees lends greater support for carbon limitation to growth. New Phytologist, 195, 285-289.

107.

Wilson, C.M., Schaeffer, R.N., Hickin, M.L., Rigsby, C.M., Sommi, A.F., Thornber, C.S. et al. (2018). Chronic impacts of invasive herbivores on a foundational forest species: a whole-tree perspective.Ecology , 99, 1783-1791.

108.

Young, T.P. \& Okello, B.D. (1998). Relaxation of an induced defense after exclusion of herbivores: spines on Acacia drepanolobium. Oecologia , 115, 508-513.

109.

Young, T.P., Stubblefield, C.H. \& Isbell, L.A. (1996). Ants on swollen-thorn acacias: species coexistence in a simple system. Oecologia , 109, 98-107.

110.

Zhang, Z., Huang, M., Zhao, X. \& Wu, L. (2019). Adjustments of leaf traits and whole plant leaf area for balancing water supply and demand in Robinia pseudoacacia under different precipitation conditions on the Loess Plateau. Agricultural and Forest Meteorology, 279, 107733.

111.

Zhou, A.M., Liang, G.W., Zeng, L., Lu, Y.Y. \& Xu, Y.J. (2017). Solenopsis invicta suppress native ant by excluding mutual exploitation from the invasive mealybug, Phenacoccus solenopsis. Pakistan Journal of Zoology, 49 .

Figure Legends (also included below figures in this draft form)

Figure 1. Leaf photosynthetic rate $\left(A_{\text {max-leaf }}\right)$, leaf transpiration rate $\left(E_{\text {leaf }}\right)$ and leaf water potential range of Acacia drepanolobium trees in Transition sites (that were invaded by P. megacephala in December 2017 after initial wet and dry season surveys) and in paired Control sites (that were protected by C. mimosae throughout the study). Effect tests are reported in each panel, with significant interactions terms indicating an effect of invasion distinct from interannual change. In wet seasons, $\mathrm{A}_{\text {max-leaf }}$ and $\mathrm{E}_{\text {leaf }}$ in Control trees were significantly lower and leaf water potential range was higher in 2018 than in 2017, yet these leaf physiological variables for Transition trees did not differ from 2017 (immediately before invasion) to 2018 ( $c a$. 6 months after invasion) (A , C ,E ). In dry seasons, trees in Transition sites had lower $A_{\text {max-leaf }}$ in 2018 ( $c a$. 9 months after invasion) than in 2017 and this difference was significantly larger than the interannual decline for Control trees (B ). Also, in dry seasons, $E_{\text {leaf }}$ increased between 2017 and 2018 for Control trees but was consistent for Transition trees (D), and leaf water potential range was consistent for all trees $(\mathbf{F})$.

Figure 2. Differences in leaf- $\left(A_{\text {max-leaf }}\right.$; i.e., per-unit-leaf-area $)$ and canopy-level $\left(A_{\text {max-canopy }}\right.$; i.e., canopy photosynthetic capacity) photosynthesis (means +- SEM) of P. megacephala - vs. C. mimosae- occupied Acacia drepanolobium adults in wet and dry seasons at long-term Invaded and Uninvaded sites. (A) Trees occupied by $P$. megacephala workers have significantly lower $A_{\text {max-leaf }}$ and $A_{\text {max-canopy }}$ than do uninvaded trees in wet conditions; (B) invaded trees have higher $A_{\text {max-leaf }} \operatorname{during} \operatorname{dry}$ conditions, but $A_{\text {max-canopy }}$ did not significantly differ for invaded and uninvaded trees during the dry season. Results of pairwise comparisons are indicated as significant $\left(* \mathrm{P}<0.05,{ }^{* *} \mathrm{P}<0.001,{ }^{* * *} \mathrm{P}<0.0001\right)$ or not significant (NS). 
Figure 3. Differences in photosynthesis (means +- SEM) of P. megacephala -occupied Acacia drepanolobium adults in a 2x2 full-factorial experiment (presence/absence of ants, large herbivores) conducted at 3 longterm Invaded sites in wet and dry seasons. Photosynthetic indices are estimated at the leaf- $\left(A_{\text {max-leaf }}\right)$ and canopy-level ( $\left.A_{\text {max-canopy }}\right)$. Results of effect tests are reported in panels. In wet seasons, $(\mathbf{A})$ vertebrate herbivory causes decline in $A_{\text {max-leaf }}$ and $(\mathbf{C})$ vertebrate herbivory and invasive ant presence both cause declines in $A_{\text {max-canopy }}$; while $A_{\text {max-leaf }}$ and $A_{\text {max-canopy }}$ are lower during dry seasons, vertebrate herbivores and invasive ant presence does not affect either response variable in dry conditions ( $\mathbf{B}$ and $\mathbf{D}$ ).

Figure 4. Differences in canopy transpiration capacity $\left(E_{\text {canopy }}\right)$ and leaf water potential range (means +- SEM) for Acacia drepanolobium adults in a 2x2 full-factorial experiment (presence/absence of ants, large herbivores) conducted at 3 long-term Invaded sites in wet and dry seasons. Significant results of effect tests are reported in subfigures (factors at left, $\mathrm{P}$ values at right; refer to main text for full output): in wet seasons, (A) vertebrate herbivory and $P$. megacephalapresence both cause declines in $E_{\text {canopy }}$ and $(\mathbf{C}$ ) invasive ant presence causes a small but significant reduction in leaf water potential range. In the dry season, (B ) vertebrate herbivory and $P$. megacephala presence both cause declines in $E_{\text {canopy }}$ but do not affect leaf water potential range (D). The diurnal change in leaf water potential $(\mathbf{C}$ and $\mathbf{D})$ is likely driven by a combination of increased transpirational water loss (A and $\mathbf{B})$ and hydraulic resistance.

\section{Figures}



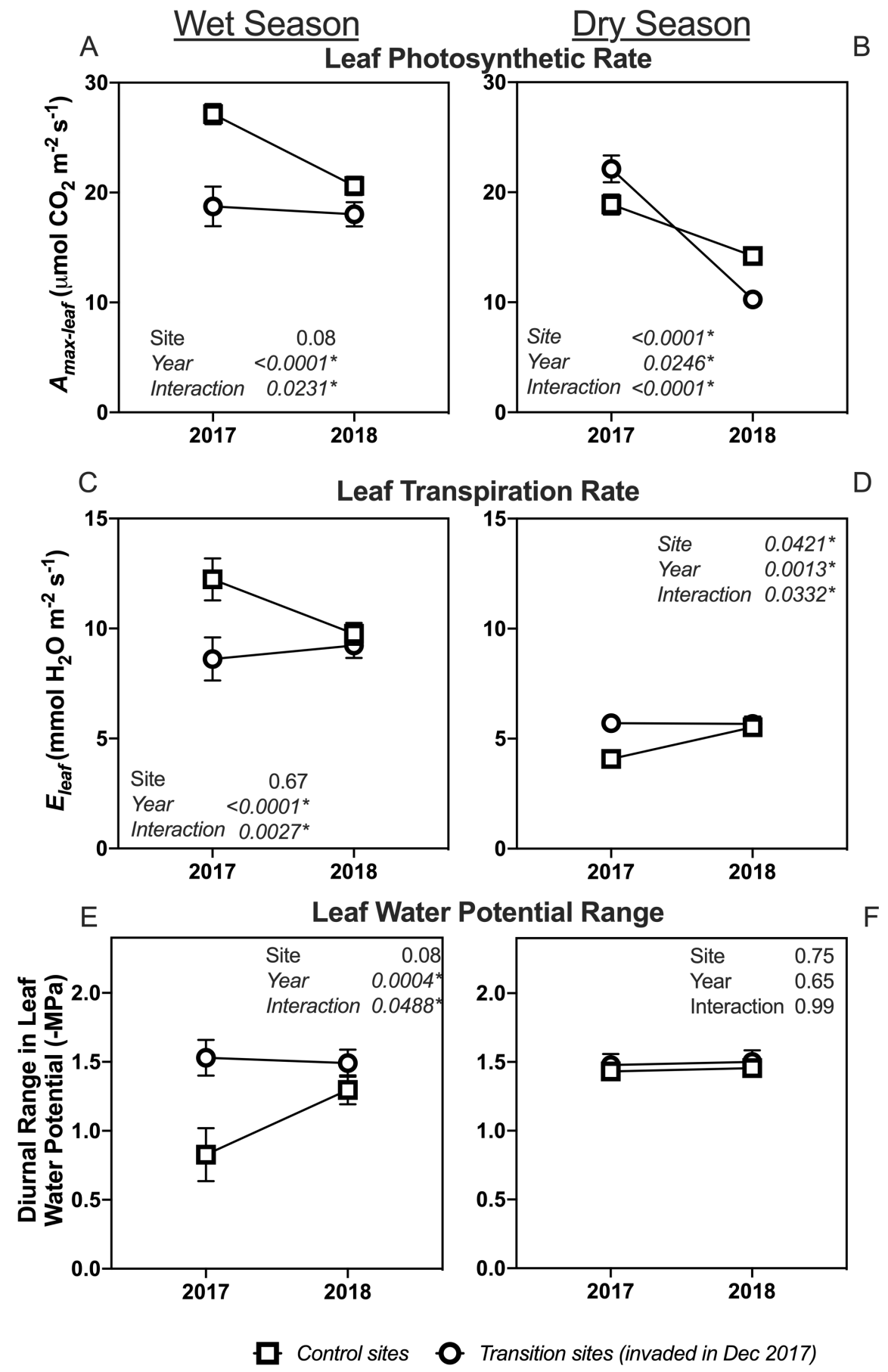

Figure 1. 


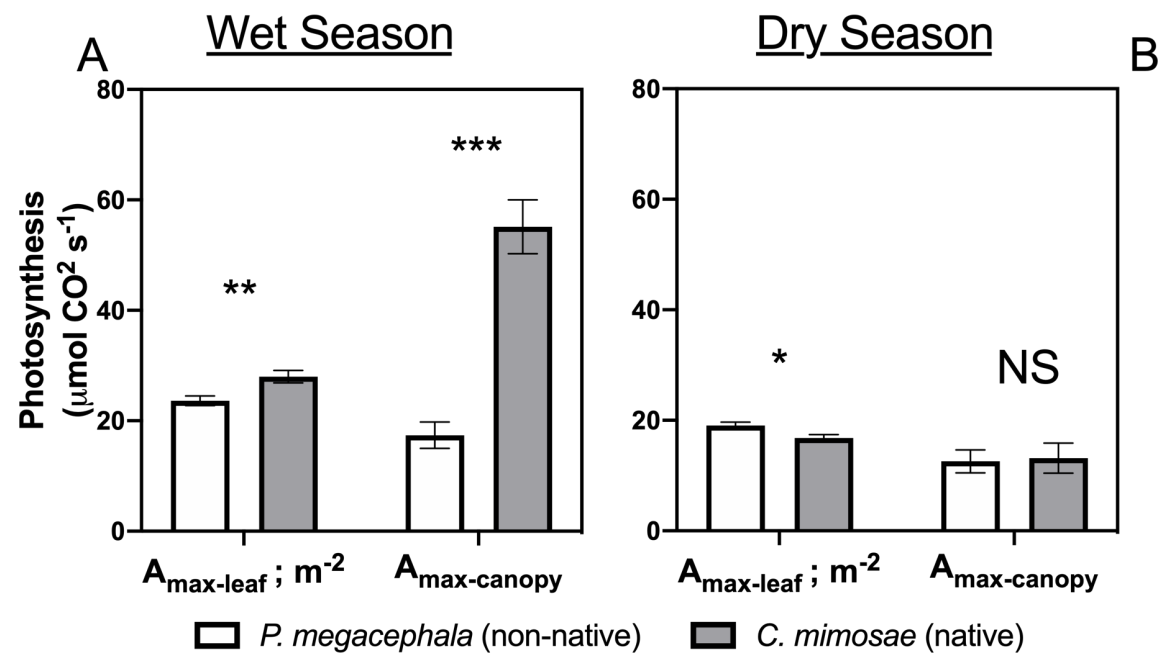

Figure 2. 
Wet Season

Dry Season
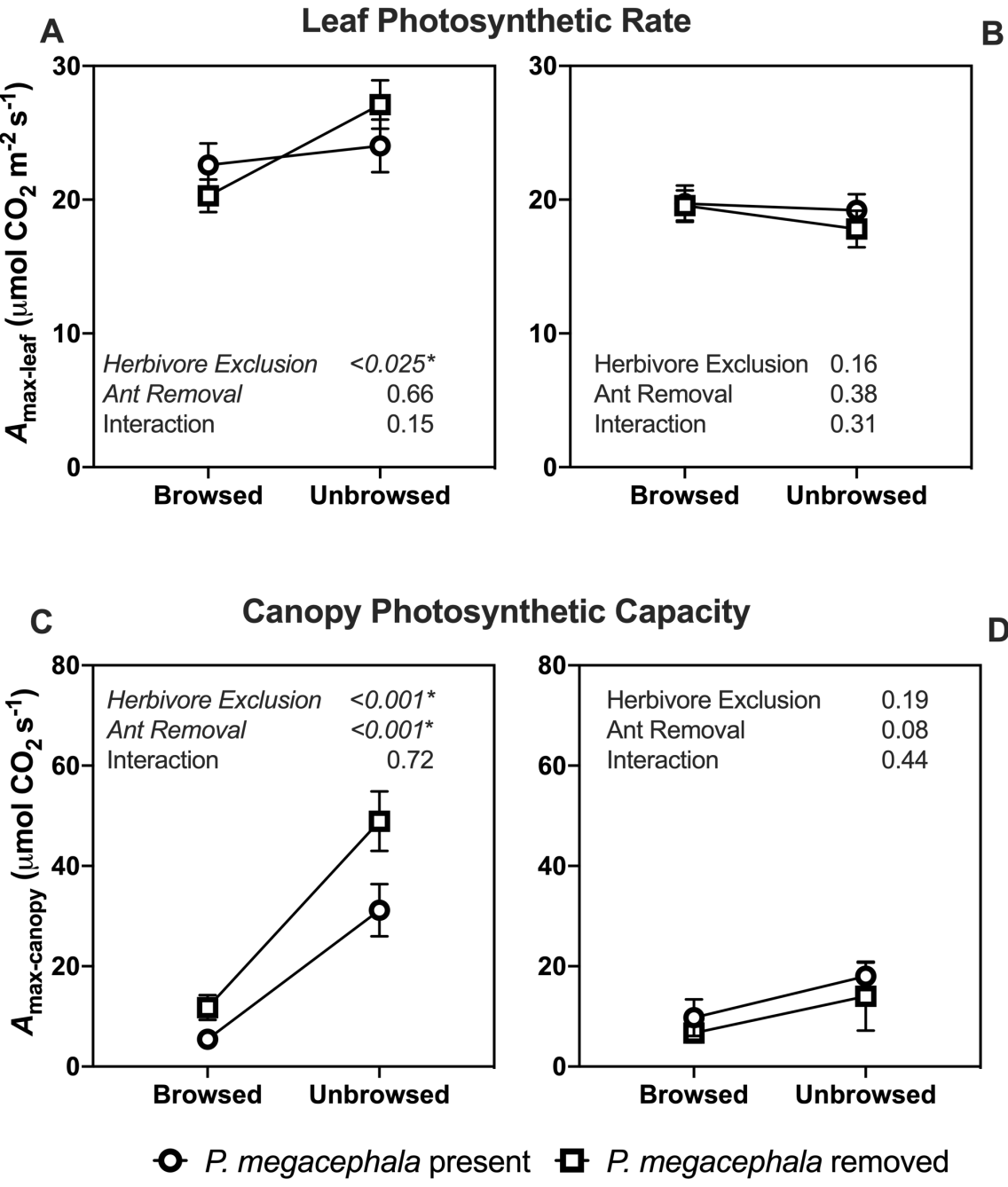

Figure 3. 


\section{Wet Season}

\section{Dry Season}
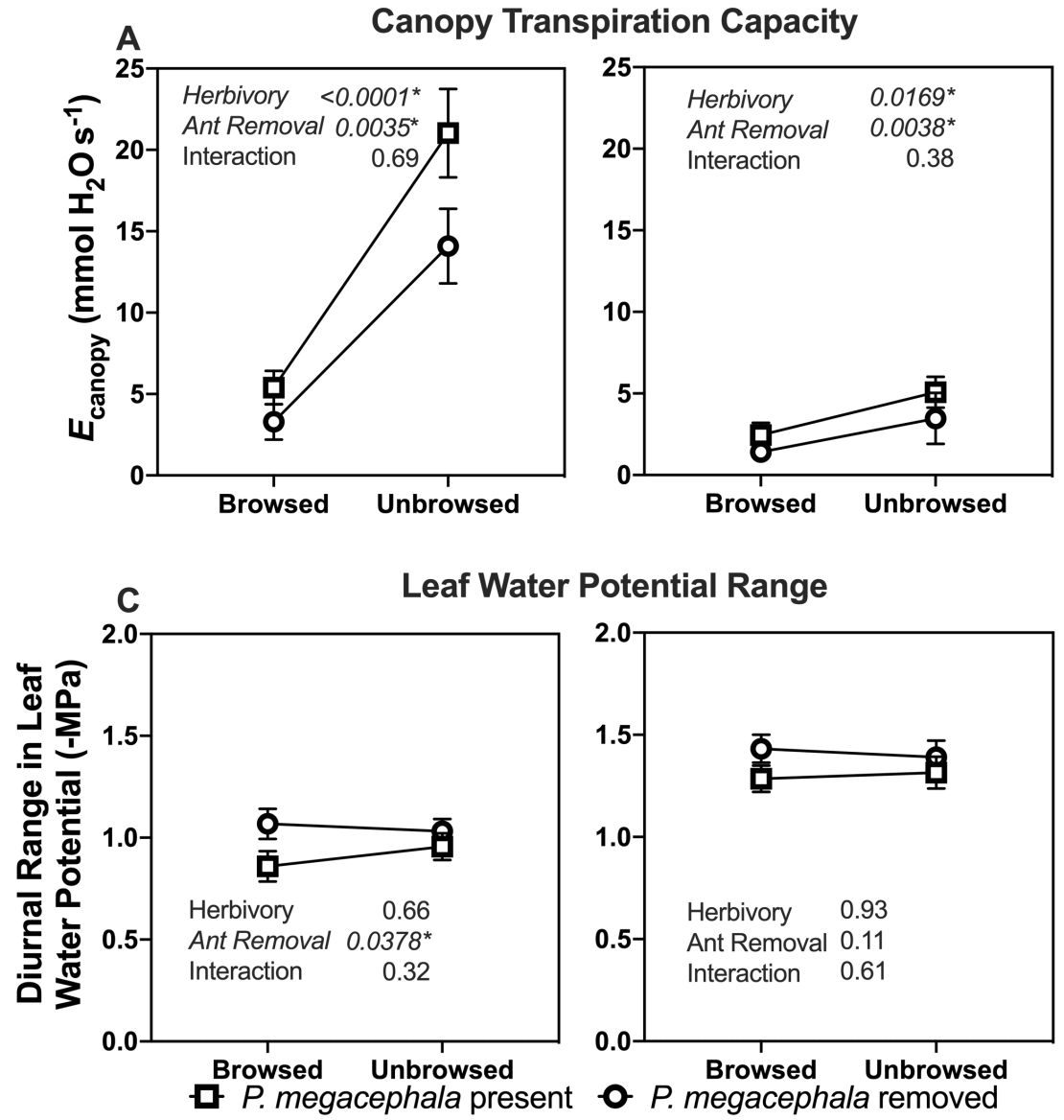

Figure 4 . 